\title{
Towards a Non-Essentialist Approach to Management Education: Philosophical Underpinnings from Phenomenography
}

\begin{tabular}{|c|c|}
\hline Journal: & Academy of Management Learning \& Education \\
\hline Manuscript ID & AMLE-2017-0401-ESS.R2 \\
\hline Manuscript Type: & Essays \\
\hline Submission Keywords: & $\begin{array}{l}\text { Educational Philosophy, Innovation in management education, Learning, } \\
\text { Management education }\end{array}$ \\
\hline Abstract: & $\begin{array}{l}\text { The classic approach to management education is manager-centric and } \\
\text { assumes there is an essential nature to management. Drawing on ideas } \\
\text { from interpretivist epistemologies, the social construction of leadership, } \\
\text { phenomenography, and variation theory, we discuss the implications for } \\
\text { management education of taking a non-essentialist approach and } \\
\text { regarding the nature of management as unknown and unknowable. We } \\
\text { focus on phenomenography for two reasons. First, when applied to the } \\
\text { task of defining management, it is built on interpretivist roots where the } \\
\text { knowledge and understanding of the observer is paramount. Second, it is } \\
\text { also a theory of learning with direct application to management research } \\
\text { and teaching. Building on these insights, we highlight the importance of } \\
\text { students becoming active investigators of management and we offer } \\
\text { practical teaching implications on how students might be encouraged to } \\
\text { engage in experiences that identify variations in the ways that } \\
\text { management is conceptualized and performed. We also consider how } \\
\text { such an approach brings a fresh perspective on what management } \\
\text { education is about, the role of the educator, and how it informs the } \\
\text { ongoing debates relating to the institutional pressures that business } \\
\text { schools face. }\end{array}$ \\
\hline
\end{tabular}




\title{
Towards a Non-Essentialist Approach to Management Education: Philosophical Underpinnings from Phenomenography
}

\author{
Jon Billsberry \\ Deakin Business School, Deakin University, Australia \\ Véronique Ambrosini \\ Department of Management, Monash Business School, Monash University, Australia \\ Mariano Garrido-Lopez \\ College of Business, Western Carolina University, USA \\ David Stiles \\ College of Business and Law, University of Canterbury, New Zealand
}




\title{
Towards a Non-Essentialist Approach to Management Education: Philosophical Underpinnings from Phenomenography
}

\author{
ABSTRACT \\ The classic approach to management education is manager-centric and \\ assumes there is an essential nature to management. Drawing on ideas from \\ interpretivist epistemologies, the social construction of leadership, \\ phenomenography, and variation theory, we discuss the implications for \\ management education of taking a non-essentialist approach and regarding the \\ nature of management as unknown and unknowable. We focus on \\ phenomenography for two reasons. First, when applied to the task of defining \\ management, it is built on interpretivist roots where the knowledge and \\ understanding of the observer is paramount. Second, it is also a theory of learning \\ with direct application to management research and teaching. Building on these \\ insights, we highlight the importance of students becoming active investigators of \\ management and we offer practical teaching implications on how students might be \\ encouraged to engage in experiences that identify variations in the ways that \\ management is conceptualized and performed. We also consider how such an \\ approach brings a fresh perspective on what management education is about, the \\ role of the educator, and how it informs the ongoing debates relating to the \\ institutional pressures that business schools face.
}


2

3

4

5

6

7

8

9

10

11

12

13

21

22

23

24

25

26

27

28

29

30

31

32

33

34

35

36

37

38

39

40

41

42

43

44

45

46

47

48

49

50

51

52

53

54

55

56

57

58

59

60

Keywords: management, non-essentialist approaches to management, phenomenography, variation theory, social construction, student-centered learning 


\section{Towards a Non-Essentialist Approach to Management Education: Philosophical Underpinnings from Phenomenography}

The progress of management learning and education is dependent on our understanding of managers, management, and managing. Despite Fayol (1916) asking questions over 100 years ago about the nature of managerial work, there is still much controversy surrounding the issue. In turn, the debate has focused on managerial roles (Drucker, 1974, Kotter, 1990a, 1990b; Mintzberg, 1973; Stewart, 1979), competences (Boyatzis, 1982), sensemaking (Weick, 2001), and more fundamentally on whether management is an art (Mangham, 1990; Spender, 2007), a science (Taylor, 1911, Rousseau, 2006; Simon, 1960), a craft (Mintzberg, 1987), or a profession (Bennis \& O’Toole, 2005; Pfeffer \& Fong, 2004; Trank \& Rynes, 2003). Uncertainty about the nature of managerial work undermines management education because it raises the fundamental question of whether or not we understand the subject we are teaching.

Such deep-seated debates are rarely won by one side or the other marshaling more evidence (Birnik \& Billsberry, 2007). Instead, new thinking is required that transcends existing divisions and reconceptualizes the debate (De Wit \& Meyer, 2004; Poole \& Van de Ven, 1989). We argue that interpretivist epistemologies, and phenomenography in particular, do so. Phenomenography denies there is an 'essence' of management waiting to be discovered. It positions management as a socially-constructed concept that forefronts students' experience of it. As such, it gives students a role in shaping how management is conceived. Hence, our main 
contribution is to advocate for a non-essentialist approach to teach management, using phenomenography to provide the philosophical foundation.

Accordingly, in this essay we first contribute arguments about the nature of management to highlight the fallacy of the essentialist mission. Building on this, we introduce phenomenography as a potential way to resolve arguments over management conceptualizations. This leads to an exploration of the implications of phenomenography for the way management is taught and its corollary implications about the mindset of the management educator. We conclude by contributing to the debate surrounding relevance and the institutional context in which business and management schools operate by discussing how the phenomenographic approach might overcome resistance.

\section{ESSENTIALIST APPROACHES TO MANAGEMENT}

Scholarly endeavor conceptualizing the nature of management has a long history. Perhaps the earliest commonly cited is Henri Fayol, a French mining engineer at the beginning of the $20^{\text {th }}$ Century. He argued managers perform five functions: prévoyance, organisation, commandement, coordination, and contrôle (Fayol, 1916), which are usually translated into English as planning (or forecasting), organizing, commanding (or directing), coordinating (or staffing), and controlling (or monitoring). Other theorists making major contributions about the nature of management in the first half of the $20^{\text {th }}$ Century include Frederick Taylor (1911), Max Weber (1914-1919), Chester Barnard (1938, 1948), and Mary Parker Follett (1942). 
Mintzberg (1973) identified three management roles comprising ten subroles: interpersonal (figurehead, leader, and liaison), informational (monitor, disseminator, and spokesperson), and decisional (entrepreneur, disturbancehandler, resource allocator, and negotiator). Addressing confusion between the concepts of leadership and management, John Kotter (1990) defined management as "coping with complexity" (1990a: 104) and controlling people "by pushing them in the right direction" (1990a: 107), whereas leadership motivates them by satisfying basic human needs.

The competence (function categorization) and competency (behavioral ability) movement of (mainly) the 1980s and 1990s argued managerial jobs could be broken down into key component parts and behaviors and these could be linked to performance (Le Deist \& Winterton, 2005; Salaman, 1995; Woodruffe, 1992). This led to a dizzying array of generic skills managers were expected to master. This approach has faded from view in business schools because the competences and competencies they contain are context-specific (Chong, 2013). As Jubb and Robotham (1997: 173) note, "Unless there are truly generic management skills, to identify a manager as being competent per se may be incorrect, as that individual may only be effective within a particular corporate environment, i.e., certain competences could be regarded as being situation-specific."

The discussion about the nature of management has shifted to broader themes. Is it a science, an art, a craft, or a profession? Whether it be Mangham's (1990) managerial performances, Rousseau's (2006) evidence-based decision making, or Weick's (2001) sensemaking, the focus is on the manager and his or her 
behavior, decisions, or persona. All these scholars were on a manager-centric mission seeking the essential truth of what managers should be or how they should act. Their research looked at French mines and American car factories in the first quarter of the $20^{\text {th }}$ Century, male Chief Executives in the late 1960s, British industry in the 1980s and 1990s, and Shakespearean theatre. They sought to find an inner truth about management and then extrapolate the findings more generically. Certainly, there are important lessons to be learned in these contexts, but there is little sense we are moving closer towards the 'essence of management'. Rather, the increasing number of perspectives suggests we are further away than ever from this goal.

The leadership literature confronted a similar issue over the last 40 years. The dominant view (cf. Uhl-Bien, Riggio, Lowe, \& Carsten, 2014) argues leadership is a quality of leaders, and many studies have sought to reveal the traits and behaviors of leaders. However, a growing theme in the leadership literature is based on social construction (e.g., Fairhurst \& Grant, 2010; Grint, 1997, 2000, 2005; Meindl, 1995; Schyns \& Meindl, 2005; Schyns \& Schilling, 2011; Tavares, Sobral, Goldszmidt, \& Araújo, 2018). This argues leadership is in the eye of the beholder, a quality of the observer rather than the leader. It is about how people perceive other people and how the actions they see match their prototypical implicit leadership theories (ILTs; Epitropaki, Sy, Martin, Tram-Quon, \& Topakas, 2013; Kenney, Schwartz-Kenney, \& Blascovich, 1996; Schyns, Kiefer, Kerschreiter, \& Tymon, 2011). This approach challenges the essentialist mission, contending leadership is fundamentally unknowable and, although influenced by others, is constructed separately in 
everyone's heads (Grint, 2005). Teaching from this perspective helps students understand their own ILTs, how these influence their actions, and explores how they can shape the leadership perceptions of others (Billsberry, 2016; Schyns \& Schilling, 2011). Hence, important leadership theories are those in people's heads, not those of researchers who, as we have shown, are bounded by their context and focus.

Our conjecture is that a similarly non-essentialist approach might bring important insights to management education. Rather than take a manager-centric approach prescribing a particular way of conceiving management, an alternative, interpretivist approach would let our students define and understand the concept in their own ways. Phenomenography is the one epistemology developed within the field of education that allows this to happen (Åkerlind, 2017; Ashworth \& Lucas, 1998; Dahlin, 2007; Lamb, Sandberg, \& Liesch, 2011; Marton, 1986; Säljö, 1997; Sandberg, 2000; Tight, 2016).

\section{PHENOMENOGRAPHY AND VARIATION THEORY}

Phenomenography is an interpretive research method for exploring the qualitatively different ways people experience phenomena. The word has Greek roots: "phainemenon" (which means, that which is revealed or manifested), and "graphein" (which means, to describe in words or pictures; Pang, 2003). Hence, phenomenography is concerned with describing the way things appear to us. Marton (1986: 31) formally defines phenomenography as a research approach for "mapping the qualitatively different ways in which people experience, conceptualize, perceive and understand various aspects of, and phenomena in, the 
world around them." The goal of phenomenographic research is to understand how people observe and make sense of the world and, in particular, the phenomenon of interest, from the perspective of respondents. This is known as an experiential or second order perspective, since the focus is on the experience-as-described, not the phenomenon itself (Ashworth \& Lucas, 1998). As such, phenomenographic research makes statements about variations in people's experiences of phenomena (Marton, 1986).

Unlike phenomenology, which is an epistemological or philosophical approach to the nature of the world (Burrell \& Morgan, 1979), phenomenography is an approach to research. Crucially, it takes other people's experience as its object of research, whereas phenomenological philosophers seek to understand their own experience (Marton \& Booth, 1997). As a first order view, phenomenology tries to describe what the world would look like pre-reflectively, or without us having learned to see it, and before we take it for granted; whereas phenomenography as a second-order perspective argues we can also discover the structure and meaning of a phenomenon through experience (Barnard et al, 1999; Marton, 1981). Phenomenography is an interpretive approach based on a non-dualistic ontology in which knowledge about the world is created through an individual's lived experience (Sandberg, 2000, 2005; Svensson, 1997).

\section{Phenomenography and learning}

Phenomenography was primarily developed in general education from studies of students' learning at Göteborg University (e.g., Marton \& Säljö, 1984; Säljö, 1979). This empirical work was initiated after a simple observation that some 
individuals have an easier learning experience than others. From this observation, two research questions emerged: "What does it mean that some students are better at learning than others?" and "Why are some students better at learning than others?" (Marton, 1994: 4424). Traditional research about learning takes the researcher's perspective as the point of departure. Marton and Svensson's (1979) idea was to reverse this and to study learning from the learner's perspective. The Göteborg team asked students to read from a book in individual sessions. Students were told they were going to discuss their understanding of this reading with the researcher. The purpose was to discover what the student had understood about the text and how they performed the task of learning about it. The analysis revealed a few distinctively different ways of approaching the text, such as understanding its purpose, understanding its logical structure, and making connections to other texts (Marton, 1975, 1986, 1994). Marton also noted these qualitatively different ways could be arranged into categories based on significant characteristics emerging from the data and students' depth of learning. These different ways of understanding appeared to be logically related and helped explain how successful students were in the learning process. The researchers had answered the first question, "What does it mean that some students are better at learning than others?" (Marton, 1994: 4424).

In exploring the second question, "Why are some students better at learning than others?" Marton (1994: 4424) found the way the students understood the text was closely related to their approaches to learning. For example, some tried to memorize, others to understand, and yet others to integrate the material with what 
they already understood. The ways people approached the learning task influenced the success and depth of their learning. Marton $(1994,2000)$ found this to be a fundamental difference in learning. One of phenomenography's greatest contributions is the identification of a hierarchy of learning separating deep and surface learning; with deeper, long lasting learning being the preferred objective (Marton, Dall'Alba, \& Beaty, 1993).

Many studies have now been conducted using the phenomenographic research approach. The findings show that any aspect of reality is understood in only a relatively limited number of different ways and this appears to be stable across situations (Marton, 1994). These qualitatively different ways are known as 'conceptions', 'ways of experiencing', or 'ways of understanding' (Sandberg, 2000).

This research also shows how richer, more complex conceptions represent, in educational terms, more complete understandings of a phenomenon. Conceptions are organized in a hierarchical structure. One of the seminal Göteborg studies, Säljö (1979), found there were five qualitatively different and hierarchically related conceptions of learning (see Figure 1). These ranged from a simple increase in knowledge to a more complete interpretative process aimed at understanding reality (cf. Bloom, 1956; Krathwohl, 2002; Marzano \& Kendall, 2007).

\section{INSERT FIGURE ONE ABOUT HERE}

\section{Variation theory}

Phenomenography has moved beyond being a research design into a new theory of learning called Variation Theory (Björklund, 2014; Kullberg, 2010; Lo, 2012; Lo \& Chik, 2016; Marton, 2015; Marton \& Booth, 1997; Rovio-Johansson \& 
Ingerman, 2016). The basic idea underpinning variation theory is that awareness of a phenomenon only occurs when it is different and contrasted to something else (Åkerlind, 2017; Marton \& Booth, 1997). Through the contrast, the components of the phenomenon can be identified (Åkerlind, 2017). Variation theory research typically goes beyond the identification of categories of description related to the underlying intention or purpose of their experience and commonly includes supplementary analysis that explores the component parts of the phenomenon (Åkerlind, 2017; Marton \& Booth, 1997). Variations in patterns of awareness and awareness deficits of component parts of a phenomenon explain the differences in the ways people understand a phenomenon. Moreover, these variations are the features that students need to identify and study to gain a deep, and complete understanding of the phenomenon (Pang \& Marton, 2005). Variation theory also implies that students will learn when they are aware of variation between their existing knowledge and their experience of new phenomena (Åkerlind, 2017).

\section{Conducting phenomenographic research}

A naïve view of phenomenography might be that it simply lets respondents register their opinions like other interpretivist approaches; but this would be incorrect. As phenomenography has developed, it has moved away from understanding the individual towards understanding individuals collectively in terms of similarities and variations in how they experience phenomena (Säljö, 1996; Tight, 2016). It is not about giving a voice to people per se; it is about making sense of how people make sense of particular phenomena. Åkerlind (2012) notes this is a common misconception about phenomenographic research. 
Phenomenographic research has three components:

1. People are asked to describe their experience of a phenomenon.

2. Researchers look to identify the distinctly different ways in which people understand the same phenomenon.

3. Researchers analyze concepts for patterns, structure, or hierarchy to understand the relationships between them.

The most common data gathering tool in phenomenography is the semistructured interview (Willis, 2017), although other methods are used that allow respondents expression largely uninfluenced by the researcher (e.g., written responses: Tight, 2016). There must be enough depth to data gathering to expose variations between responses, and when interviews are employed, the interviewer may interject to clarify his or her understanding (Bowden, 2000). Willis (2017) suggests the research questions should focus on participants' experience (e.g., What is your experience of effective management?) rather than their views or opinions (e.g., What benefits does effective management bring?).

Most phenomenographic studies employ simple and straightforward data gathering and analysis and do not require large data sets. They typically use between 20 and 30 interviewees (Åkerlind, 2005; Bowden, 2005; Marton \& Booth, 1997; Tight, 2016; Trigwell, 2000) with theoretical saturation usually achieved with a sample size of around 20 respondents (Alexandersson, 1994; Sandberg, 2000; Bowden \& Green, 2005). This relatively low sample size and apparent simplicity makes the approach appealing but may lead to skepticism, particularly in relation to how the researcher has determined the structure of conceptions. Reading and 
understanding transcripts is not a major problem in itself, but finding meaningful variation is a challenge that has been tackled in numerous ways (Åkerlind, 2005; Bowden \& Walsh, 1994, 2000). The most common method is to adopt an iterative process with multiple interrogations of the data from different perspectives (See Åkerlind (2005: 325-326) for detailed examples of how different researchers approach this categorization task).

\section{Critiques of phenomenography and variation theory}

There are challenges to designing and undertaking phenomenography and variation theory research. First of all, there is the problem of 'the Other' (Webb, 1997). Phenomenography purports to see the world through the eyes of the research participants and map the qualitatively different ways in which they experience, conceptualize, perceive, and understand various aspects of it. This gives the impression phenomenography is researcher-neutral and merely the recorder of participants' understandings. However, confounding factors include the researcher's involvement in the shaping of the research question, the gathering of data, and a hermeneutic element to the analysis of it. Hence, there is always a tension in phenomenographic research between the researcher and 'the Other'; a phenomenographic researcher may claim to understand the world from other's perspective, but it is done on the researcher's terms.

A second criticism is that phenomenography is overly rational and overly cognitive. It assumes knowledge can be extracted from participants and recorded independently of the person whose knowledge it is (Åkerlind, 2005; Bowden, 2000; Bowden \& Green, 2005). This sits very uncomfortably with a non-dualistic 
interpretive ontology where knowledge is inseparable from the person. Moreover, it is largely silent on non-cognitive factors such as emotion. This is important because learning and emotion are intertwined and interdependent (Antonocopoulou \& Gabriel, 2001). For example, people may be aware of different things based on their emotional state: A worried person is likely to interpret signals differently to a calm or confident one; while an anxious person may be less forthcoming about their views than a relaxed one. Such emotions may, of course, be a variation in themselves and worthy of further analysis.

The findings of phenomenographic research imply that 'deep' learning is good and 'surface' learning is bad (Marton, 2015; Marton \& Booth, 1997). This is because deep learning is believed to show understanding, whereas surface learning is about memorizing (Webb, 1997). This hierarchical valuation is implicit in the question "What does it mean that some students are better at learning than others?" (Marton, 1994: 4424). In overlaying this normative assessment, it denies the moments when surface learning is preferred, appropriate, or justified.

These are important criticisms that question the validity of the conceptions that are generated (Webb, 1997); there could be occasions when these are just as much the constructions of the researcher as they are the original views of the interviewees. At the very least, these criticisms provide useful reminders that phenomenography needs to be employed sensitively always keeping in mind the focus should be on the perceptions and experiences of the interviewees. It is their understanding and awareness of the phenomenon that the researcher is interested in and this necessitates close attention to the processes by which it is surfaced 
minimizing power asymmetries; the approach is interested in, grounded in, and owned by the Other (Webb, 1997).

\section{TEACHING MANAGEMENT FROM A PHENOMENOGRAPHIC PERSPECTIVE: A}

\section{CALL TO ACTION}

Traditional approaches to teaching management typically begin with applying ideas about management (e.g., Fayol, Mintzberg, competences) to students' current and anticipated jobs. Lessons from the analogous developments in the leadership literature discussed earlier suggest that adopting a non-essentialist approach to management education will mean focusing on the perceptions and experiences of students. From the outset of their studies, management students would be confronted with the reality that there is no universal managerial prototype. Instead, they would be given activities requiring them to discover the nature of management in their current or future work environments. They would also be encouraged to surface their own 'implicit management theories' and consider how these might bias their thoughts and actions towards managers, management, and managing. It is a very different approach that would have students experience management and be helped to find explanations for variations in how they conceptualize it. In effect, it would turn them into active investigators of the phenomenon rather than passive recipients of past conceptualizations.

\section{Making students' perspectives central}

If postgraduate students are (or have been) employed in organizations, a phenomenographic approach would have the educator facilitate the conceptualization of management in students' own terms. Exercises would be set for 
students to analyze their managerial experiences and, once their theories of management have been generated, compare these with other students' experiences, and use this variation to drive their understanding of management.

While postgraduate management students may be expected to have some experience of the target phenomenon, undergraduate students may not, unless they are mature entrants. If they have come straight from school, they are unlikely to have had much management experience. Given phenomenography assumes students will have direct and meaningful experience of the phenomenon under consideration, this is a major problem. Fortunately, management educators have many learning techniques at their disposal that they can use to give their undergraduate students direct experience of management so that they are able to construct their own understanding of the phenomenon (Itin, 1999; Lo \& Chik, 2016). These experiential methods include service learning (Kenworthy-U'Ren \& Peterson, 2005), job shadowing (Czarniawska, 2014), internships (Maertz, Stoeberl, \& Marks, 2014), project-based learning (Helle, Tynjälä, \& Olkinuora, 2006), and study tours (Sachau, Brasher, \& Fee, 2010). They are typically prolonged encounters where students are immersed in new experiences. Management educators also use shorter exercises where students learn by reflecting on particular activities such as simulations, games, and exercises (Keys \& Wolfe, 1990; Landers \& Callan, 2011; Salas, Wildman, \& Piccolo, 2009). These can be effective phenomenographic activities as they acknowledge students' own perspectives of the managerial phenomenon, although the situational drivers are likely to be strong (Herriot \& Pemberton, 1995; Schneider, 1987). 
With experiential learning, all students have their own experience of the event and will draw lessons for themselves. Many cognitive and perceptual biases (e.g., fundamental attribution error, false-consensus bias, and self-serving bias) limit the learning that can come from within-person comparisons (i.e., comparing what you know with what you have observed). Instead, the phenomenographic management educator should seek comparison across the student cohort and will facilitate discussion and reflective dialogue in the classroom about differences in perception, experience, and the resulting conceptualization of management. Åkerlind (2017) provides guidance on how to maximize students' chances of discerning variation and thereby gain a better understanding of management in their contexts. She says students' experience must include contrast, generalization, separation, and fusion. This involves (1) comparing students' experiences of effective management with less and differently experiences of the phenomenon, (2) considering varying occurrences of effective management, (3) considering how factors influencing effective management might be isolated from other factors, and (4) observing how all the factors influencing effective management vary simultaneously in relation to each other so that critical elements might be identified. Here, the greatest challenge for the phenomenographic educator is to tease out variation across students' experiences while maintaining relevance to each individual student's situation.

\section{Assessing learning}

Phenomenography is primarily an approach to the design of educational research (Åkerlind, 2017; Marton, 1994; Tight, 2016). As such, it does not always 
offer easy application to the design of teaching. One example is the assessment of students' learning and, in particular, on what counts as learning. Phenomenography evaluates learning from the students' perspective, not from the educator's. Those with an andragogic perspective may favor a phenomenographic approach, since they already appreciate the role of experienced students in establishing learning objectives (Forrest \& Peterson, 2006; Knowles, 1980). However, pedagogic philosophies still hold sway, as seen in recent interest in adopting assessment rubrics in management education (Riebe \& Jackson, 2014). Rubrics outline the standards educators consider satisfactory evidence to show students are achieving desired learning outcomes. This is driven from the educators' perspective, since it assumes educators know a priori what students need to learn and demonstrate. It is at odds with an observer-centric approach to knowledge where definitions of management and analyses of its effectiveness are constructed in students' minds. Instead, therefore, phenomenographic assessment focuses on the depth and richness of students' understanding of their own managerial experiences and how these are informed by variation with other assessments rather than their knowledge of the academic subject.

\section{The phenomenographic management educator's mindset}

Advances in the field of phenomenography challenge many of our underlying assumptions about education, learners, and how to teach. For management educators, the disconcerting consequence of a non-essentialist approach is the public recognition that we do not and cannot be definite about the nature of management. Instead of being expert purveyors of expert knowledge on 
management, we become facilitators of an experiential process that develops, runs, and debriefs students' managerial experiences. In addition to new teaching skills, a phenomenographic perspective may require a change of mindset. Educators may lose the confidence that comes from knowing more about the subject than the learners. That said, it will still be important to understand past investigations of management as the context against which phenomenographic teaching is positioned. This knowledge may provide direction against which students can analyze their experiences.

Our call for a shift to a phenomenographic teaching approach and increased adoption of experiential techniques comes at a time when management educators are under increasing pressure to focus efforts on research publication in highranking journals (Vogel, Hattke, \& Petersen, 2017). Recruitment and promotion are increasingly determined by publication records (Harley, in press). In such an environment, the rational person may prefer to focus their efforts on research. However, increasing competition for space in leading journals (Macdonald \& Kam, 2011) and the tendency towards accuracy rather than relevance (Harley, 2015) is causing many to question the impact of current management research (e.g., Cornelissen, 2016; Sandberg \& Tsoukas, 2011). Refocusing management teaching on phenomenography offers an alternative approach to achieve relevance and impact. Instead of management scholars engaging in research primarily driven by increasingly narrow requirements of academic journals (Corbett, Cornellisen, Delios, \& Harley, 2014; Delbridge \& Fiss, 2013; Harley, 2015; Miller, Taylor, \& 
Bedeian, 2010), they would be more engaged in research projects driven by the interests of their students.

\section{Institutional considerations}

We have advocated a major shift in the way students are taught in business schools. Although elements of experiential approaches are commonly found in business schools, they are rarely central in management education. Instead, students attend classes in which they are passive recipients of management research; they learn about management rather than how to manage. This is a consequence of institutional pressures to accommodate large volumes of students in popular management courses simultaneously reducing costs to a minimum to maximize business schools' financial contribution (Harley, 2018; Pfeffer \& Fong, 2002). As Pfeffer and Fong (2004: 1509) note, "The wealth [of Business Schools] has ... occasionally been covetously eyed by central university administrations, which particularly in public universities but also in many private ones, have come to see business schools as cash cows, as ways of raising money for the 'center' through various taxes imposed on schools [...]. This latter behavior has resulted in the paradoxical situation of the more money and enrolment schools bring in, the more they are expected to bring in, with business schools in a rat race they can never really win." Hence, these institutional pressures are strong.

Other forces are gaining strength that may cause institutions to invest more in the quality of their teaching. In their seminal work, Pfeffer and Fong (2002) suggested that business schools do not provide either what students need or what they want. Similarly, in their review of MBAs, Rubin and Dierdorff (2013) reflect on 
the lack of evidence about students' actual learning and the inadequacy of many curricula. Around the world, there has been a trend towards increasing 'costsharing', a euphemism for transferring the costs of education to students (Johnstone, 2004). This policy has resulted in high levels of student debt in many countries (Elliott \& Lewis, 2015; Owens, 2016; Phillips, Wilbanks, Salinas, \& Doberneck, 2016; Seligren, 2014; Xu, Johnson, Bartholomae, O’Neill, \& Gutter, 2015) and increasing student activism demanding value for money and input into where their fees go, particularly to improve the quality of teaching (Neves \& Hillman, 2018). These pressures are being reflected in the foci of the accreditation bodies (e.g., AACSB, AMBA, EQUIS) whose gaze is skewed towards the promises business schools make to students and quality of the product they receive (Alajoutsijärvi, Kettunen, \& Sohlo, 2018; Barton, Billsberry, Ambrosini, \& Barton, 2014).

Our call for action has echoes in several current debates on the promotion of student engagement and active involvement. For instance, it is reflected in articles suggesting that we should move away from the student-as-customer approach and towards a student-as-partner approach (Ferris, 2003) whereby students are considered to be co-producers of knowledge (Finney \& Finney, 2010). This line of argument is becoming increasingly salient with ever more business schools signing up to the United Nations' Principles for Responsible Management Education (PRME) initiative whose tenets include the education of ethical and responsible students, the grounding of business education in the reality of day to day managerial work, and students' full engagement in their learning (Nonet, Kassel, \& Meijs, 2016). Both phenomenography and a non-essentialist approach to teaching management are 
fully aligned with these principles. In addition to advancing this conversation, we have embraced the conceptions of student-as-partner and co-creator of knowledge and explored a new approach to management teaching that would embed learning in the concerns of our students.

\section{CONCLUSION}

We began by querying the essentialist manner of management research and teaching. We were concerned that while there are many theories purporting to define managers and management, they all come from an essentialist perspective where it is assumed that there is an ideal way of performing. Our analysis explored the consequences of taking a non-essentialist view of management and applied the phenomenographic approach with its interpretivist roots to the problem. Rather than assuming the nature of management or effective management might be a knowable and definite phenomenon, the phenomenographic approach regards management as a phenomenon that is experienced and understood differently by everyone.

This different perspective may have a profound impact upon the way we choose to teach management. Rather than telling our students what management is, phenomenography would encourage educators to help students conceptualize management for themselves. This involves considering the nature of effective management where students work or aspire to work. It also means they consider the consequences of their new understandings for their future development. Rather than being passive recipients of knowledge, students would be taught to become proactive learners seeking out knowledge and understanding for themselves. They 
may be offered multiple managerial experiences and guided to develop new theories of management relevant to them.

Phenomenography changes our point of focus as management educators and researchers. Despite its interpretivist roots, it is not simply about people's perceptions. At its core is not the learner or the educator, as we see in many management education studies, but the object or phenomenon around which teaching is designed. As Runesson (2006: 408) says, "A significant feature of variation theory is its strong focus on the object of learning. This enables us to get hold of aspects other than organization and methods in general in the learning situation." As such, phenomenography draws management educators into the students' world and their issues. 


\section{References}

Åkerlind, G. S. 2012. Variation and commonality in phenomenographic research methods. Higher Education Research and Development, 31: 115-127.

Åkerlind, G. S. 2017. What future for phenomenographic research? On continuity and development in the phenomenography and variation theory research tradition. Scandinavian Journal of Educational Research, online, DOI: 10.1080/00313831.2017.1324899.

Åkerlind, G. S. 2005. Variation and commonality in phenomenographic research methods. Higher Education Research \& Development, 24: 321-334.

Alajoutsijärvi, K., Kettunen, K., \& Sohlo, S. 2018. Shaking the status quo: Business accreditation and positional competition. Academy of Management Learning \& Education, 17: 203-225.

Alexandersson, M. 1994. Focusing teacher consciousness: What do teachers direct their consciousness towards during their teaching. In I. Carlgren, G. Handal \& S. Vaage (Eds.), Teachers' minds and actions. Research on teachers' thinking and practice (pp. 139-149). London: Falmer Press.

Antonocopoulou, E.P. \& Gabriel, Y. 2001. Emotion, learning and organizational change: towards an integration of psychoanalytic and other perspectives. Journal of Organizational Change Management, 14: 436-451.

Ashworth, P., \& Lucas, U. 1998. What is the "world" of phenomenography? Scandinavian Journal of Educational Research, 42: 415-431. 
Barnard, A., McCosker, H., \& Gerber, R. 1999. Phenomenography: A qualitative research approach for exploring understanding in health care. Qualitative Health Research, 9: 212-226.

Barnard, C. 1938. The functions of the executive. Cambridge, MA: Harvard University Press.

Barnard, C. 1948. Organization and management. Cambridge, MA: Harvard University Press.

Barton, L., Billsberry, J., Ambrosini, V., \& Barton, H. 2014. Convergence and divergence dynamics in UK and French business schools: How will the pressure for accreditation influence these dynamics? British Journal of Management, 25: 305-319.

Bennis, W. G., \& O'Toole, J. 2005. How Business Schools lost their way. Harvard Business Review, 83(5): 96-104.

Billsberry, J. 2016. Once learned, never forgotten: Effective leadership development with social construction as a threshold concept. Development and Learning in Organizations: An International Journal, 30: 24-26.

Birnik, A., \& Billsberry, J. 2007. Reorienting the Business School agenda: The case for relevance, rigor, and righteousness. Journal of Business Ethics, 82: 985-999.

Björklund, C. 2014. Powerful teaching in preschool: A study of goal-oriented activities for conceptual learning. International Journal of Early Years Education, 22: 380-394. 
Bloom, B. S. (Ed.). 1956. Taxonomy of educational objectives: The classification of educational goals handbook. Part 1: Cognitive domain. White Plains, NY: Longman.

Bowden, J. A. 2000. The nature of phenomenographic research. In J. A. Bowden \& E. Walsh (Eds.), Phenomenography: 1-18. Melbourne, Australia: RMIT University Press.

Bowden, J. A. 2005. Reflections on the phenomenographic team research process. In J. A. Bowden \& P. Green (Eds.), Doing developmental phenomenography: 11-31. Melbourne: RMIT University Press.

Bowden, J. A., \& Green, P. (Eds.), 2005. Doing developmental phenomenography. Melbourne: RMIT University Press.

Bowden, J. A., \& Walsh, E. (Eds.) 1994. Phenomenographic research: Variations in method. Melbourne: RMIT University Press.

Bowden, J. A., \& Walsh, E. (Eds.) 2000. Phenomenography. Melbourne: RMIT University Press.

Boyatzis, R. E. 1982. The competent manager: A model for effective performance. New York: John Wiley.

Burrell, G., \& Morgan, G. Sociological paradigms and organizational analysis: Elements of the sociology of corporate life. London: Heinemann.

Chong, E. 2013. Managerial competencies and career advancement: A comparative study of managers in two countries. Journal of Business Research, 66: 345353. 
Corbett, A., Cornellisen, J., Delios, A., \& Harley, B. 2014. Variety, novelty, and perceptions of scholarship in research on management and organizations: An appeal for ambidextrous scholarship. Journal of Management Studies, 51: 318.

Cornelissen, J. P. 2017. Preserving theoretical divergence in management research: Why the explanatory potential of qualitative research should be harnessed rather than suppressed. Journal of Management Studies, 54: 368-383.

Czarniawska, B. 2014. Why I think shadowing is the best field technique in management and organization studies. Qualitative Research in Organizations and Management: An International Journal, 9: 90-93.

Dahlin, B. 2007. Enriching the theoretical horizons of phenomenography, variation theory and learning studies. Scandinavian Journal of Educational Research, 51: $327-346$.

De Wit, B., \& Meyer, R. 2004. Strategy: Process, content, context, 3rd Edition. London: Thomson Learning.

Drucker, P. 1974. Management: Tasks, responsibilities, practices. New York: Harper and Row.

Elliott, W., \& Lewis, M. 2015. Student debt effects on financial well-being: Research and policy implications. Journal of Economic Surveys, 29: 614-636.

Epitropaki, O., Sy, T., Martin, R., Tram-Quon, S., \& Topakas, A. 2013. Implicit leadership and followership theories "in the wild": Taking stock of information-processing approaches to leadership and followership in organizational settings. The Leadership Quarterly, 24: 858-881. 
Fairhurst, G. T., \& Grant, D. 2010. The social construction of leadership: A sailing guide. Management Communication Quarterly, 24: 171-210.

Fayol, H. 1916. Administration industrielle et générale. Bulletin de la Société de l'Industrie Minérale. 10: 5-162.

Finney, G. T., \& Finney, Z. R. 2010. Are students their universities' customer? An exploratory study. Education + Training, 52: 276-291.

Follett, M. P. 1942. Dynamic Administration: The Collected Papers of Mary Parker Follett. London: Pitman.

Forrest, S. P., \& Peterson, T. 0. 2006. It's called andragogy. Academy of Management Learning and Education, 5: 113-122.

Grint, K. 1997. Reading Tolstoy's wave. In K. Grint (Ed.), Leadership: Classical, contemporary, and critical approaches (pp. 1-26). Oxford, UK: Oxford University Press.

Grint, K. 2000. The arts of leadership. Oxford, UK: Oxford University Press.

Grint, K. 2005. Leadership: Limits and possibilities. Basingstoke, UK: Palgrave.

Harley, B. 2015. The one best way? 'Scientific' research on HRM and the threat to critical scholarship. Human Resource Management Journal, 25: 399-407.

Harley, B. In press. Confronting the crisis of confidence in management studies: Why senior scholars need to stop setting a bad example. Academy of Management Learning \& Education.

Helle, L., Tynjälä, P., \& Olkinuora, E. 2006. Project-based learning in post-secondary education-theory, practice and rubber sling shots. Higher Education, 51: 287-314. 
Herriot, P., \& Pemberton, C. 1995. Competitive advantage through diversity: Organizational learning from difference. London: Sage.

Itin, C. M. 1999. Reasserting the philosophy of experiential education as a vehicle for change in the 21st century. Journal of Experiential Education, 22: 91-98.

Johnstone, D. B. 2004. The economics and politics of cost sharing in higher education: comparative perspectives. Economics of Education Review, 2: 403-410.

Jubb, R., \& Robotham, D. 1997. Competences in management development: Challenging the myths. Journal of European Industrial Training, 21: 171175.

Kenney, R. A., Schwartz-Kenney, B. M., \& Blascovich, J. 1996. Implicit leadership theories: Defining leaders described as worthy of influence. Personality and Social Psychology Bulletin, 22: 1128-1143.

Kenworthy-U'Ren, A. L., \& Peterson, T. O. 2005. Service-learning and management education: Introducing the "WE CARE" approach. Academy of Management Learning \& Education, 4: 272-277.

Keys, B., \& Wolfe, J. 1990. The role of management games and simulations in education and research. Journal of Management, 16: 307-336.

Knowles, M. 1980. The modern practice of adult education. From pedagogy to andragogy (2nd edn.). Englewood Cliffs, NJ: Prentice Hall.

Kotter, J. P. 1990a. What leaders really do. Harvard Business Review, May-June, 103111. 
Kotter, J. 1990b. A force for change: How leadership differs from management. New York: Free Press.

Krathwohl, D. R. 2002. A revision of Bloom's taxonomy: An overview. Theory into Practice, 41: 212-218.

Kullberg, A. 2010. What is taught and what is learned: Professional insights gained and shared by teachers of mathematics (Göteborg Studies in Educational Sciences, 293). Göteborg, Sweden: Acta Universitatis Gothoburgensis.

Lamb, P., Sandberg, J., \& Liesch, P. W. 2011. Small firm internationalisation unveiled through phenomenography. Journal of International Business Studies, 42: 672-693.

Landers, R. N., \& Callan, R. C. 2011. Casual social games as serious games: The psychology of gamification in undergraduate education and employee training. In Serious games and edutainment applications (pp. 399-423). Springer, London.

Le Deist, F. D., \& Winterton, J. 2005. What Is competence? Human Resource Development International, 8: 27-46.

Lo, M. L. 2012. Variation theory and the improvement of teaching and learning (Göteborg Studies in Educational Sciences, 323). Göteborg, Sweden: Acta Universitatis Gothoburgensis.

Lo, M. L., \& Chik, P. P. M. 2016. Two horizons of fusion. Scandinavian Journal of Educational Research, 60: 296-308. 
Maertz Jr., C. P., Stoeberl, P. A., \& Marks, J. 2014. Building successful internships: lessons from the research for interns, schools, and employers. Career Development International, 19: 123-142.

Mangham, I. L. 1990. Managing as a performing art. British Journal of Management, 1: 105-115.

Marton, F. 1975. On non-verbatim learning. Scandinavian Journal of Psychology, 16: $273-279$.

Marton, F. 1981. Phenomenography - Describing conceptions of the world around us. Instructional Science, 10: 177-200.

Marton, F. 1986. Phenomenography - A research approach to investigating different understandings of reality. Journal of Thought, 21: 28-49.

Marton, F. 1994. On the structure of teachers' awareness. In I. Carlgren, G. Handal \& S. Vaage (Eds.), Teachers' minds and actions. Research on teachers' thinking and practice. London: Falmer Press.

Marton, F. 2000. The structure of awareness. In J. A. Bowden \& E. Walsh (Eds.), Phenomenography: 102-116. Melbourne, Australia: RMIT University Press. Marton, F. 2015. Necessary conditions of learning. New York \& London: Routledge. Marton, F., \& Booth, S. 1997. Learning and awareness. Lawrence Erlbaum Associates, USA.

Marton, F., Dall'Alba, G., \& Beaty, E. 1993. Conceptions of learning. International Journal of Educational Research, 19: 277-300. 
Marton, F., \& Säljö, R. 1984. Approaches to learning. In F. Marton, D. J. Hounsell \& N. J. Entwistle (Eds), The experience of learning. Edinburgh: Scottish Academic Press.

Marton, F., \& Svensson, L. 1979. Conceptions of research in student learning. Higher Education, 8: 471-486.

Marzano, R. J., \& Kendall, J. S. 2007. The new taxonomy of educational objectives (2nd ed.). Thousand Oaks, CA: Corwin.

Macdonald, S., \& Kam, J. 2011. The skewed few: People and papers of quality in management studies. Organization, 18: 467-475.

Meindl, J.R. 1995. The romance of leadership as a follower-centric theory: A social constructionist approach. The Leadership Quarterly, 6: 329-341.

Miller, A., Taylor, S., \& Bedeian A. 2010. Publish or perish: Academic life as management faculty live it. Career Development International, 16: 422-445

Mintzberg, H. 1973. The nature of managerial work. London: Harper \& Row. Mintzberg, H. 1987. Crafting strategy. Harvard Business Review, 65: 66-75.

Neves, J. \& Hillman, N. 2018. 2018 Student Academic Experience Survey. York and Oxford, UK: Advance HE and the Higher Education Policy Institute.

Nonet, G., Kassel, K., \& Meijs, L. 2016. Understanding responsible management: Emerging themes and variations from European business school programs. Journal of Business Ethics, 139: 717-736.

Owens, J. 6 Apr 2016. University student HECS debt to explode to $\$ 11$ bn by 2026. The Australian Online. Downloaded from http://www.theaustralian.com.au/national-affairs/university-student-hecs- 
debt-to--explode-to-11bn-by-2026/newsstory/7e3384ae4acde6e3b018c2582df321bc on 28 April 2016.

Pang, M. 2003. Two faces of variation: On continuity in the phenomenographic movement. Scandinavian Journal of Educational Research, 47: 145-156.

Pang, M. F., \& Marton, F. 2005. Learning theory as teaching resource: Enhancing students' understanding of economic concepts. Instructional Science, 33: 159-191.

Pfeffer, J., \& Fong, C. T. 2002. The end of Business Schools? Less success than meets the eye. Academy of Management Learning \& Education, 1: 78-95.

Pfeffer, J., \& Fong, C. T. 2004. The Business School 'business': Some lessons from the US experience. Journal of Management Studies, 41: 1501-1522.

Phillips, J. P., Wilbanks, D. M., Salinas, D. F., \& Doberneck, D. M. 2016. Educational debt in the context of career planning: a qualitative exploration of medical student perceptions. Teaching and Learning in Medicine, 1-9.

Poole, M. S., \& Van de Ven, A. H. 1989. Using paradox to build management and organization theories. Academy of Management Review, 14: 562- 578.

Riebe, L., \& Jackson, D. 2014. The use of rubrics in benchmarking and assessing employability skills. Journal of Management Education, 38: 319-344.

Rousseau, D. M. 2006. Is there such a thing as "evidence-based management"? Academy of Management Review, 31: 256-269.

Rovio-Johansson, A., \& Ingerman, Å. 2016. Continuity and development in the phenomenography and variation theory tradition. Scandinavian Journal of Educational Research, 60: 257-271. 
Rubin, R. S., \& Dierdorff, E. C. 2013. Building a better MBA: From a decade of critique toward a decennium of creation. Academy of Management Learning \& Education, 12: 125-141

Runesson, U. 2006. What is it possible to learn? On variation as a necessary condition for learning. Scandinavian Journal of Educational Research, 50: 397-410.

Sachau, D., Brasher, N., \& Fee, S. 2010. Three models for short-term study abroad. Journal of Management Education, 34: 645-670.

Salaman, G. 1995. Managing. Buckingham, UK: Oxford University Press.

Salas, E., Wildman, J. L., \& Piccolo, R. F. 2009. Using simulation-based training to enhance management education. Academy of Management Learning \& Education, 8: 559-573.

Säljö, R. 1979. Learning in the learner's perspective: some common sense conceptions. Reports from the Department of Education. Gothenburg: University of Gothenburg.

Säljö, R. 1996. Minding action: Conceiving of the world versus participating in cultural practices. In G. Dall'Alba \& B. Hasselgren (Eds.), Reflections on phenomenography: Toward a methodology? (pp. 19-33). Goteborg: Goteborg Studies in Educational Sciences 109.

Säljö, R. 1997. Talk as data and practice - a critical look at phenomenographic inquiry and the appeal to experience. Higher Education Research \& Development, 16: 173-190. 
Sandberg, J. 2000. Understanding human competence at work: An interpretive approach. Academy of Management Journal, 43: 9-25.

Sandberg, J. 2005. How do we justify knowledge produced within interpretive approaches? Organizational Research Methods, 8: 41-68.

Sandberg, J., \& Tsoukas, H. 2011. Grasping the logic of practice: Theorising through practical rationality. Academy of Management Review, 36: 338-360.

Schneider, B. (1987). The people make the place. Personnel Psychology, 40: 437453.

Schyns, B., Kiefer, T., Kerschreiter, R., \& Tymon, A. 2011. Teaching implicit leadership theories to develop leaders and leadership: How and why it can make a difference. Academy of Management Learning \& Education, 10: 397-408.

Schyns, B., \& Meindl, J. R. 2005. Leadership horizons series: Vol. 3. Implicit leadership theories: Essays and explorations. Charlotte, NC: Information Age Publishing Inc.

Schyns, B., \& Schilling, J. 2011. Implicit leadership theories: Think leader, think effective? Journal of Management Inquiry, 20: 141-150.

Seligren, K. (10 Apr 2014). Students could be paying loans into their 50s - report. BBC News website. Downloaded from http://www.bbc.com/news/education-26954901 on 28 April 2016.

Simon, H. A. 1960. The new science of management decision.

Spender, J. 2007. Management as a regulated profession: An essay. Journal of Management Inquiry, 16: 32-42. 
Stewart, R. 1979. The reality of management. London: Macmillan.

Svensson, L. 1997. Theoretical foundations of phenomenography. Higher Education Research \& Development, 16: 159-171.

Tavares, G. M., Sobral, F., Goldszmidt, R., \& Araújo, F. 2018. Opening the implicit leadership theories' black box: An experimental approach with conjoint analysis. Frontiers in Psychology, 9: 1-11.

Taylor, F. W. 1911. The principles of scientific management. New York: Harper.

Tight, M. 2016. Phenomenography: The development and application of an innovative research design in higher education research. International Journal of Social Research Methodology, 19: 319-338.

Trank, C. Q., \& Rynes, S. L. 2003. Who moved our cheese? Reclaiming professionalism in business education. Academy of Management Learning and Education, 2: 189-205.

Trigwell, K. 2000. A phenomenographic interview on phenomenography. In J. Bowden \& E. Walsh (Eds.), Phenomenography (pp. 62-82). Melbourne, Australia: RMIT University Press.

Uhl-Bien, M., Riggio, R. E., Lowe, K. B., \& Carsten, M. K. 2014. Followership theory: A review and research agenda. Leadership Quarterly, 25: 83-104.

Vogel, R., Hattke, F., \& Petersen, J. 2017. Journal rankings in management and business studies: What rules do we play by? Research Policy, 46: 1707-1722.

Webb, G. 1997. Deconstructing deep and surface: Towards a critique of phenomenography. Higher Education, 33: 195-212. 
Weber, M. 1914-1919, translated 2015. Weber's rationalism and modern society: New translations for the $21^{\text {st }}$ Century. New York: Palgrave Macmillan.

Weick, K. E. 2001. Making sense of the organization. Oxford: Blackwell.

Willis, A. S. 2017. The efficacy of phenomenography as a cross-cultural methodology for educational research. International Journal of Research \& Method in Education, online, DOI: http://dx.doi.org/10.1080/1743727X.2017.1283398

Woodruffe, C. 1992. What is meant by competency? In R. Boam, \& P. Sparrow (Eds.), Designing and achieving competence. London: McGraw-Hill.

Xu, Y., Johnson, C., Bartholomae, S., O'Neill, B., \& Gutter, M. S. (2015). Homeownership among Millennials: The deferred American dream? Family and Consumer Sciences Research Journal, 44: 201-212. 
Figure One

Säljö’s (1979) Five Conceptions of Learning

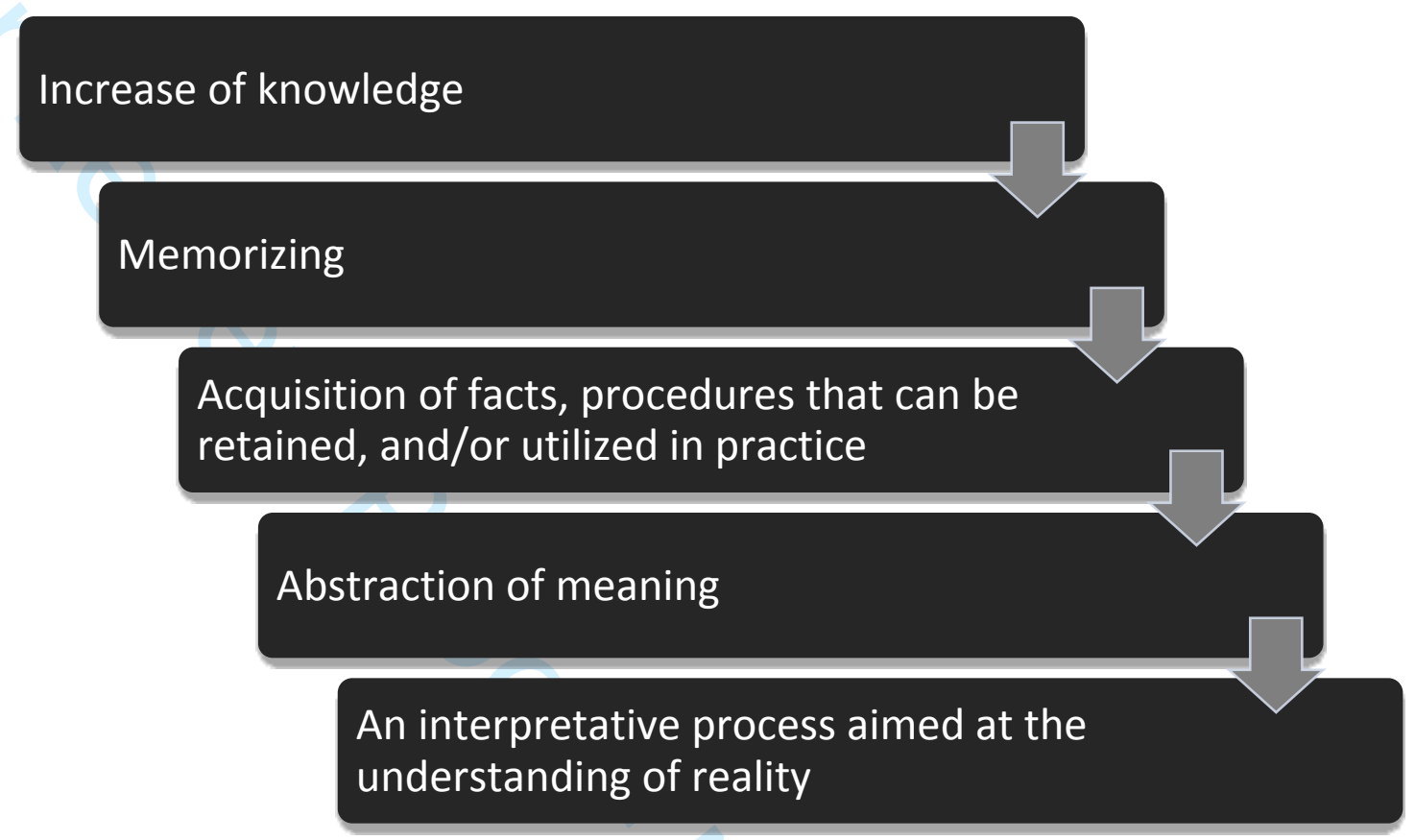

